\title{
Small Arms Survey 2013: Una amenaza cotidiana. \\ Capítulo 9. Puntos de inflexión: La evolución de las pandillas en Nicaragua
}

\section{Dennis Rodgers y José Luis Rocha}

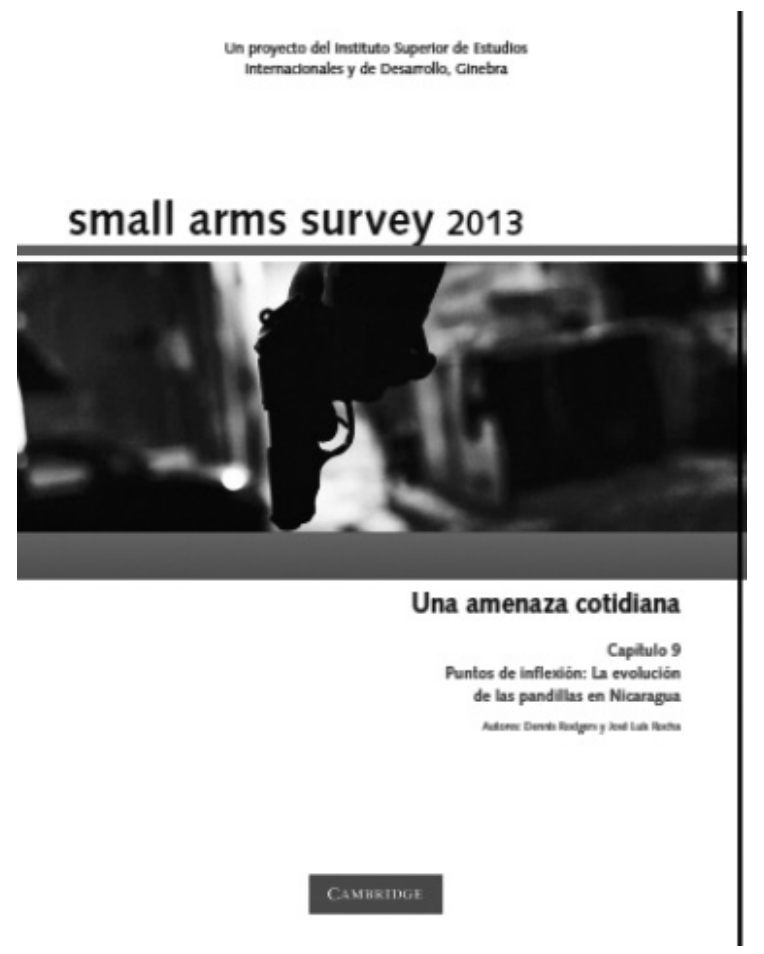

Este capítulo se apoya en un trabajo de campo profundo y de largo plazo con el fin de ofrecer un análisis comparitivo de la trayectoria evolutiva, durante el período posterior a la guerra fría, de las pandillas asociadas a dos barrios de Managua, la capital de Nicaragua: Elías Blanco y Luis Fanor Hernández (estos nombres son seudónimos). Se centra en las tendencias cambiantes en el uso de armas ligeras por parte de los miembros de las pandillas, explorando los diferentes tipos de armas que han usado en diversos momentos de su historia, la naturaleza variable del mercado clandestino de armas, el apogeo y la decadencia de los actores armados, y la evolución constante de la relación entre pandillas y sus comunidades locales.

El capítulo puede descargarse libremente del sitio Web del Small Arms Survey: http:// www.smallarmssurvey.org/ 